\title{
Mampukah Model Multi Faktor APT Memberikan Gambaran Hubungan Return Harapan Portofolio Saham LQ45 Dengan Resiko Sistematik Pada Pasar Modal Indonesia
}

\author{
Penulis : Yuki Dwi Darma ${ }^{1}$
}

1 STIE Pelita Bangsa

\begin{abstract}
Abstrak
Tujuan penelitian ini adalah untuk menguji model APT sebagai model keseimbangan harga pasar modal dalam memprediksi return saham-saham yang tergabung dalam indeks LQ45. Desaim penelitian menggunakan penggujian multipass Regression dalam menguji validitas dan keandalam model CAPM dengan data-data yang digunkan dalam penelitian ini merupakan harga penutupan saham-saham LQ45 dan return bulanan indeks LQ45, varibel digunakan menggunakan kurs US Dollar, Inflasi dan risiko pasar. Untuk analisis data menggunakan two Stage Regresion menggunakan regresi time Series pada tahap satu dan regresi Cross Sectional pada regresi tahap dua. Hasil penelitian menemukan bahwa model APT kurang berkerja dengan baik dalam memprediksi harga saham di pasar modal Indonesia, terutama saham-saham yang tergabung dalam LQ45. Risiko Pasar tidak mampu menjelaskan hubungan risiko ekonomi makro terhadap imbal hasil rata-rata portofolio yang dibentuk dalam penelitian ini.
\end{abstract}

Keywords: APT, Return Saham, Portofolio, LQ45, Cross Sectional, Time Series, Two Stage Regression, Resiko Sistematik, Resiko Non-sistematik, Return Harapan, Variabel Ekonomi Makro, variabel residual.

Corresponding author: Yuki Dwi Darma (yuki@ pelitabangsa.ac.id)

\section{Pendahuluan}

Semenjak ditemukannya teori portofolio efisien oleh Hendry Markowitch (1950), maka peneliti-peneliti sesudahnya berlomba-lomba menciptakan model keseimbangan pasar modal. Model keseimbangan pasar modal yang pertama kali muncul adalah Capital Assets Pricing Model atau lebih dikenal dengan CAPM yang diperkenalkan oleh Sharpe (1964) yang merupakan revolusi baru di dunia investasi dimana investasi dapat dinilai, atau return ekstra apa yang akan diterima investor berkenaan dengan tingkat resiko yang dihadapi (Fama \& French, 2004), lebih lanjut pada model ini hanya menekankan pada resiko pasar return harapan dari portofolio sekuritas. Sesudah CAPM diperkenalkan, banyak bermunculan model-model keseimbangan pasar modal dengan menawarkan hubungan antara risiko dan imbal hasil yang lebih baik, salah satunya yang terkenal adalah Arbiterage Pricing Theory (APT) yang diperkenalkan oleh Ross (1976), merupakan model keseimbangan pasar modal yang paling unggul dalam memprediksi hubungan antara imbal hasil sekuritas dengan variabel ekonomi makro termasuk risiko spesifik perusahaan juga diperhitungkan. 
Model CAPM, APT dan Model 3 Faktor bersaing dalam menawarkan penjelasan alternatif tentang hubungan antara risiko dan return. CAPM diterima secara luas sebagai teknik yang tepat untuk mengevaluasi aset keuangan. Hal ini digunakan untuk membangun portofolio, mengukur kinerja manajemen investasi, mengembangkan tingkat proyek skrining untuk penganggaran modal, dan nilai perusahaan. Beta dihitung dan ditampilkan berdasarkan indeks pasar yang digunakan. Para pendukung Teori Harga Arbitrage (APT), yang menawarkan penjelasan alternatif tentang hubungan antara risiko dan return, walaupun penerapannya masih terbatas dalam dunia keuangan dikarenakan kerumitan penentuan faktor yang cocok (Authors, 2017).

Prinsip dalam model keseimbangan harga pada model APT (Arbiterage Pricing Theory) sebenarnya terletak pada bagaimana kedua aset yang sama bisa mengalami kesalahan harga sehingga akan membuka peluang arbiterase terhadap keuntungan yang didapatkan investor tanpa adanya risiko yang akan dihadapi, ini dikarenakan aktivitas pembelian dan penjualan sekuritas secara simultan untuk mendapatkan laba dari perbedaan harga yang terjadi (Bodie \& Kane, 2014). Sesuai dengan teori keseimbangan pasar modal, bahwa peluang arbiterase akan hilang karena pasar modal akan membentuk keseimbangan baru dengan melakukan tekanan yang kuat pada pola arbiterase yang terjadi. Sesuai dengan kaidah teori Law of One Price bahwa dua aset yang ekuivalen dalam seluruh aspek ekonomis yang relevan akan menghasilkan harga aset yang sama.

Model APT yang diperkenalkan oleh Ross (1976) merupakan sebuah model yang elegan dalam menjelaskan hubungan antara return dan resiko. APT sendiri menawarkan asumsi yang lebih sedikit ketimbang model CAPM. Hasil yang diperoleh pada hubungan cross sectional tentang hubungan antara return dan resiko lebih menarik pada berbagai studi empiris yang berlawanan dengan usulan CAPM. Model APT yang dikembangkan pertama kalinya oleh Ross (1976) merupakan model periode tunggal dimana setiap investor yakin bahwa reeturn stokastik terhadap sekuritas dari harga aset adalaha konsisten dengan sebuah stuktur faktor. Seperti dibahas sebelumnya, CAPM hanya menggunakan potofolio pasar sebagai pusat dari hubungan harga aset. Tetapi sejumlah pengujian empiris pada CAPM seperti Gibbon (1982), Reinganum (1981), Lakonishok dan Shapiro (1986) tidak dapat menyajikan bukti yang kuat tentang hubungan antara return harapan dengan beta pasar yang mengindikasikan terdapat kelemahan pada model CAPM. Akan tetapi temuan bertolak belakang dengan

Tujuan dari penelitian ini adalah melakukan pengujian empiris terhadap APT dalam memprediksi retun aset dengan menggunakan sejumlah variabel ekonomi makro. Meskipun pada penelitian ini, memasukkan variabel-variabel untuk mewakili faktor APT, juga dapat dianggap mewakili beta CAPM multi. Beberapa 
temuan yang relevan dan menyajikan bukti bahwa APT menggunakan variabel makro ekonomi dapat menyebabkan perkiraan sedikit lebih baik dari risiko dan hasil yang diharapkan dari CAPM dan model keseimbangan pasar modal lainnya seperti model 3 Faktor (Fama and French, 2002; Baghdadabad \& Glabadanidis, 2014).

Penelitian lain (Geske dan Roll, 1983) yang meneliti hubungan fiskal, moneter, dan inflasi. Geske dan Roll menyimpulkan ada hubungan sebab akibat diantara faktor yang diteliti. Dalam penelitian dengan variabel makro ekonomi yang meneliti 25 variabel makro ekonomi industri, menunjukkan bahwa variabel makro ekonomi dan industri sangat penting untuk menjelaskan pengembalian aset. Sama halnya yang dilakukan oleh Cagnetti (2002) yang menggunakan 25 variabel ekonomi makro dalam melakukan pengujian pada pasar modal Itali. Selanjutnya Flannery dan Protopapadakis (2002) menyimpulkan bahwa indeks produk industri dan indeks harga konsumen (Consumer Price Indexs) berpengaruh secara signifikan terhadap return portofolio yang dibentuk pada tingkatan tertentu. Al-Khazali dan Pyun (2004) meneliti tentang hubungan tingkat inflasi di wilayah Asia-Pasifik seperti Australia, Hongkong, Jepang, Korea Selatan, Indonesia, Malaysia, Philipina, Singapura dan Thailand pada periode 1980 sampai dengan 2001 den menyimpulkan bahwa terdapat hubungan negatif dengan harga saham jangka pendek. Dalam model APT terdapat suatu kelemahan mendasar dalam menentukan faktor-faktor ekonomi mana saja yang mempengaruhi return sekuritas, seperti halnya Atlay (2003) dalam menguji model dimana menggunakan analisa faktor (Faktor Analysis) untuk mencari faktor-faktor ekonomi yang relevan. Penelitian ini dilakukan untuk melakukan investigasi dan menyelidiki tentang kesesuaian model APT sebagai model keseimbangan harga pasar modal dalam memprediksi dan manggambarkan hubungan antara return dan resiko pada sahamsaham yang tergabung dalam LQ45 (Rjoub et al., 2009).

\section{Rumusan Masalah}

Perkembangan pasar modal di Indonesia telah mengami perkembangan yang sangat pesat, terlihat dari banyaknya emiten yang tergabung menjadi anggota bursa, selain itu banyak perusahaan yang memberikan informasi keuangan yang lebih baik ketimbang pasar modal 10 tahun yang lalu. Seperti biasanya, model keseimbangan pasar modal sering digunakan oleh analis investasi dan manajer investasi untuk menentukan keputusan investasi terhadap sekuritas-sekuritas yang diperdagangkan di pasar modal. Seperti yang ulas pada latar belakang masalah, bahwa model APT mampu memberikan penjelasan lebih baik ketimbang model keseimbangan pasar modal lainnya (CAPM, Model 3 faktor) dengan menghubungkan antara imbal hasil sekuritas dengan faktor ekonomi makro. Oleh sebab itu timbul pertanyaan : 
Seberapa baikkah model APT mampu menjelaskan hubungan antara imbal hasil portofolio saham menggunakan basis syariah dengan faktor ekonomi makro dan khusus pada pasar modal Indonesia saat ini?

\section{Kajian Teori}

\section{APT (Arbiterage Pricing Theory)}

Model ini pertama kali diperkenalkan oleh Ross (1976), kerangka model APT pada umumnya menggambarkan hubungan linier antara return harapan dan jumlah faktor-faktor umum yang direkomendasikan dari asumsi ekspektasi investor yang homogenous (sejenis), memaksimalkan utilitas nilai pemegang saham serta bagian kecil (friction) pasar persaingan sempurna tanpa arbiterase. (Altlay, 2003).

Eksploitasi kesalahan harga dari suatu sekurutas dengan cara tertentu menyebabkan keuntungan bisa diperoleh tanpa resiko disebut arbiterase (arbiterage) yang melibatrkan aktifitas pembelian dan menjual sekuritas yang sama secara simultan untuk memperoleh laba pada perbedaan harga yang terjadi, kemudian pasar modal akan segera meniadakan peluang arbiterase. Model multifaktor ini digunakan untuk mengukur dan mengelola eksposur setiap faktor ekonomi makro berskala luas seperti resiko siklus bisnis, resiko tingkat bunga, resiko inflasi, resiko harga energi dan sebagainya. Selanjutnya model faktor dikombinasikan dengan kondisi tanpa peluang arbiterase yang akan mendorong pada hubungan sederhana antara return harapan dan resiko yang disebut APT. Lebih lanjut, arbiterase diartikan sebagai sebuah tindakan/kegiatan yang menghasilkan keuntungan yang positif tanpa mengeluarkan modal dan tanpa resiko yang akan ditanggung.

Dalam model APT biasanya lebih dari satu faktor yang dimasukkan dengan tujuan untuk melihat perilaku saham terhadap faktor-faktor tersebut yang biasanya dikenal dengan model multi faktor, model ini sangat berguna dalam analisa keuangan modern untuk mengukur eksposur sekuritas terhadap suatu resiko ekonomi, serta dapat membentuk suatu portofolio guna melakukan lindung nilai terhadap resiko tersebut. Misalkan yang terdapat pada model 2 faktor yang dinyatakan dengan persamaan sebagai berikut :

$$
r_{i}=E\left(r_{i}\right)+\beta_{i 1} F_{1}+\beta_{i 2} F_{2+} \varepsilon_{i}
$$

Maka premi resiko faktor 1 merupakan eksposur portofolio atas faktor 1, dimana beta 1 dikali dengan premi diterima portofolio I atas faktor $1\left(\beta_{i 1}\left[E\left(r_{1}\right)-r_{f}\right]\right)$ ditambah beta 2 dikali premi diterima portofolio I atas faktor $2\left(\beta_{i 2}\left[E\left(r_{2}\right)-r_{f}\right]\right)$ 
Menurut Charles P. Jones (2010) Terdapat beberapa asumsi dari CAPM yang juga dipakai dalam APT, tetapi ada juga asumsi CAPM yang tidak dipakai dalam APT, singkatnya APT merupakan penyederhanaan asumsi CAPM yaitu :

Asumsi-asumsi yang dipakai dalam CAPM dan APT

1. Investor memiliki kepercayaan yang seragam (Homogenous beliefs)

2. Investor merupakan penghindar resiko dalam memaksimalkan utilitas

3. Pasar dalam keadaan seimbang

4. Return dihasilkan oleh sebuah model faktor

Asumsi-asumsi yang dipakai dalam CAPM tetaapi tidak dipakai dalam APT

1. Semua investor memiliki rentang waktu satu periode yang sama (similar investment horizon).

2. Tidak adanya pajak

3. Meminjam dan meminjamkan pada tingkat bunga bebas resiko

4. Investor memilih portofolio berdasarkan kriteria mean-varian

\section{Pembentukan Harga Arbiterase}

Teori APT diperkenalkan oleh Stephen Ross tahun 1976 yang memprediksi garis pasar sekuritas yang menghubungkan antara return harapan sekuritas dengan resiko dimana jalur SML sedikit berbeda. APT sebenarnya didasarkan pada tiga proporsi yaitu :

1. Return sekuritas dapat dijelaskan dengan model faktor .

2. Terdapat banyak sekuritas untuk menghilangkan resiko istimewa dengan diversivikasi.

3. Pasar modal bekerja dengan baik dalam menghilangkan kesempatan arbiterase.

Sebenarnya peluang arbiterase ini terjadi jika investor memperoleh laba yang tidak beresiko tanpa melakukan investasi, misalnya saham dijual dengan harga yang berbeda pada pada pasar modal yang berbeda sehingga memperoleh keuntungan tanpa mengeluarkan modal. (Law of One Price) menyebutkan jika dua aset yang identik tidak bisa dijual dengan harga yang berbeda, dan terjadi penyimpangan maka timbul tindakan arbiterase dimana membeli aset di tempat murah kemudian menjual ditempat mahal sampai pasar akan menghilangkan kesempatan tersebut. Berbeda dengan CAPM yang menyebutkan semua investor memegang portofolio efisien secara rata-rata dan varian dimana akan meningkatkan portofolio pada sekuritas murah (underpriced) dan melepas pada harga terlalu mahal (over priced).

model APT sendiri memiliki kesimpulan yang identik dengan CAPM, misalnya adanya hubungan lininer antara return dengan resiko, namun APT memiliki asumsi-asumsi yang berbeda dengan CAPM yang tidak 
berdasarkan aturan varian. Ross menjelaskan hubungan linier antara return dan resiko muncul karena tidak adanya peluang arbiterase.

Asumsi mendasar tentang APT dimana return diperoleh dari suatu proses yang identik dengan model multi faktor atau faktor tunggal (single-multifaktor), dimana kovarian yang muncul antara return sekuritas berkaitan dengan faktor-faktor pemicunya sehingga tercipta hubunga linier antara return dengan faktorfaktor tersebut. Kemudian return pada saham I pada periode t diasumsikan dihitung dengan persamaan sebagai berikut (Baghdadabad \& Glabadanidis, 2014):

$$
r_{i, t}=A_{j}+\beta_{1, i} I_{1, t}+\beta_{2, i} I_{2, t}+\cdots+\beta_{n, i} I_{n, t}+e_{i, t}
$$

Dimana

$I \quad=$ nilai faktor mempengaruhi tingkat return saham

Aj = intersep yang merupakan return harapan sekuritas yang tergantung pada kenyataan bahwa semua faktor memiliki nilai nol (tidak berpengaruh terhadap sekuritas).

Beta individu dapat berupa angka positif atau negatif dari faktor ke faktor dan dari saham ke saham.

$e_{i, t} \quad=$ merupakan faktor spesifik perusahaan yang merupakan komponen residual yang tidak akan berkorelasi antar perusahaan.

Kemudian varian residual atau faktor spesifik perusahaan ditunjukkan dengan persamaan berikut

$$
\sigma^{2}(E p)=\sum_{j=1}^{n} X^{2} j \sigma^{2}\left(E_{j}\right)
$$

Maka, dapat dihitung varian portofolio dalam bentuk multi faktor sebagai berikut :

$$
\sigma^{2}\left(r_{p}\right)=\beta_{1 p}{ }^{2}{\sigma_{1}}^{2}+\beta_{2 p}{ }^{2} \sigma^{2}\left(I_{2}\right)+\cdots+\beta_{n p}{ }^{2} \sigma^{2}\left(I_{n}\right)+\sigma^{2}(E p)
$$

Dimana beta masing-masing faktor merupakan rata-rata tertimbang dari beta-beta sekuritas dalam portofolio yangdinyatakan dalam rumus :

$$
\beta_{1 p}=\sum_{j=1}^{n} X_{j} \beta_{1, j}
$$

Selanjutnya menurut APT yang menjadi dasar penentu harga aset adalah resiko dan return harapan dimana APT memiliki prosedur dan asumsi yang berbeda dengan CAPM, APT mengenal ada beberapa resiko yang mempengaruhi return sekuritas. APT berasumsi return aset berhubungan linier dengan sejumlah indeks, dimana setiap indeks mewakili sebuah faktor yang mempengaruhi return sekuritas. Faktor-faktor resiko tersebut merupakan pencerminan dari kekuatan ekonomi dan bukan sifat khusus perusahaan, yang mana faktor yang dimaksud harus memiliki 3 sifat yaitu :

1. Setiap faktor harus memiliki pengaruh menyebar pada return sekuritas. 
2. Faktor-faktor tersebut secara dominan harus mempengaruhi return harapan.

3. Pada setiap awal periode, faktor-faktor resiko harus tidak dapat diprediksi terhadap keseluruhan pasar.

Model APT sendiri berasumsi bahwa investor percaya bahwa return aset secara acak diperoleh sesuai dengan $n$ faktor untuk sekuritas $i$ dimana return sebenarnya dapat dinyatakan dengan rumus

$$
R_{i}=E\left(R_{1}\right)+\beta_{1, i} f_{1}+\beta_{2, i} f_{2}+\cdots+\beta_{n, i} f_{n}+\varepsilon_{1}
$$

Dimana :

$R_{i} \quad=$ tingkat pengembalian sebenarnya pada sekuritas $i$ pada periode $\mathrm{t}$.

$E\left(R_{1}\right)=$ return harapan sekuritas $i$

$\beta_{i} \quad=$ sensitifitas sekuritas $i$ terhadap faktot.

$\varepsilon_{1} \quad=$ kesalahan acakk yang unik terhadap sekuritas $i$.

$f \quad=$ penyimpangan faktor sistematik $\mathrm{F}$ dari harapannya, biasanya nilai harapan masing-masing faktor F adalah nol, maksudnya jika $F_{1}-E\left(F_{1}\right)=0$ maka $F_{2}-E\left(F_{2}\right)=0$ dan seterusnya.

Jika ditransformasikan dalam model keseimbangan tentang return harapan yang memerlukan model faktor. Persamaan return harapan terhadap suatu sekuritas adalah :

$$
E\left(R_{i}\right)=a_{0}+\beta_{1, i} \bar{F}_{1}+\beta_{2, i} \bar{F}_{2}+\cdots+\beta_{n, i} \bar{F}_{n}
$$

Dimana :

$E\left(R_{i}\right)=$ Return harapan sekuritas $\mathrm{i}$

$a_{0} \quad=$ return sekuritas i yang memiliki resiko sistematis adalah nol

$\bar{F} \quad=$ premi resiko suatu faktor $\left[E\left(\bar{F}_{n}\right)-a_{0}\right]$

Dalam APT, resiko diartikan dalam bentuk sensitivitas sekuritas terhadap faktor ekonomi dasar, sementara itu return harapan secara langsung terkait dengan sensitifitas. Kemudian return harapan return-resiko digambarkan dengan model sebagai berikut :

$$
\left.E\left(R_{1}\right)=r_{f}+\beta_{i, 1} \text { (premi resiko faktor } 1\right)+\cdots+\beta_{i, n}(\text { premi resiko faktor } 1)
$$

The Arbiterage Pricing Teory (APT) berdasarkan pada hukum satu harga. Hukum tersebut mengatakan bahwa semua barang dengan resiko yang sama seharusnya dijual pada harga yang sama dengan demikian pasar dapat mencapai keseimbangan yang akan mencegah arbiterase (Authors, 2017). Ada persyaratan lebih lanjut mirip dengan asumsi-asumsi tentang CAPM yang berhubungan dengan efisiensi pasar, kepercayaan yang homogen dari investor dan rata-rata varians-kriteria investasi mereka. Asumsi ini memastikan bahwa 
tidak ada kesempatan arbitrase dan pasar berada dalam kesetimbangan apa yang penting untuk APT. Sthepan Ross (1976) ada delapan persyaratan yang dibutuhkan untuk signifikansi APT:

1. Tidak adanya biaya transaksi

2. Aset dipecah/dibagi-bagi

3. Short Selling dan long buys tidak terbatas

4. Investor dapat meminjam pada tingkat bebas resiko

5. Tidak ada hambatan terhadap penjualan dan pembelian aset

6. Keputusan berdasarkan kriteria mean-variance

7. Keputusan investor individu tentang posisi mereka dalam setiap aset tidak akan mempengaruhi harga

Asumsi diatas sebahagian cocok dengan Indonesian Stock Exchange (Bursa Efek Indonesia). Pertama-tama di Bursa Efek Indonesia terdapat biaya transakasi, tetapi ukuran transaksi sangat besar, biaya relatif akan kecil bahkan biaya tersebut dapat diabaikan. Dalam dunia bisnis yang nyata, unit terkecil yang dapat diperdagangkan di pasar nyata adalah satu saham yang tidak dapat dibagi menjadi beberapa bagian dan kemudian diperdagangkan. Namun demikian, dapat diduga bahwa pelaku pasar berinvestasi dalam pembelian satu saham mahal. Dengan asumsi ini situasi saham dapat dilihat terpisah.

\section{APT multi faktor}

Diasumsikan banyak faktor ekonomi makro sistematis yang mempengaruhi return saham, seperti tingkat suku bunga, laju inflasi, harga minyak, harga emas dan lain sebagainya. Eksposur salah satu faktor akan mempengaruhi resiko dan return saham tersebut. Setiap faktor dan komponen spesifik perusahaan memiliki return harapan nol, karena setiap variabel kejutan bukan tingkat variabel dalam variabel sistematis. Dalam pembentukan APT multifaktor sama halnya dengan APT faktor tunggal yang mengacu pada konsep portofolio faktor yang terdiversifikasi dengan baik disebut sebagai portofolio tracking yang melacak sumber ekonomi makro tertentu tetapi tidak berkorelasi dengan sumber resiko lain.

M,enurut teori bahwa APT berasumsi bahwa investor yakin terhadap vektor nx1 dari return acak periode tunggal pada modal aset yang dapat dijelaskan dengan model faktor Sehingga persamaan dapat menjadi seperti berikut :

$$
r_{i}=E\left(r_{i}\right)+\beta f+e_{i}
$$


Dimana e adalah sebuah vektor nx 1 dari variabel acak, f adalah sebuah vektor kx 1 dari variabel acak (faktorfaktor), $E\left(r_{i}\right)$ merupakan sebuah vektor $\mathrm{nx} 1$ dan $\beta$ adalah sebuah matrik $\mathrm{nxm}$ dengan syarat $\mathrm{E}(\mathrm{f})=0, \mathrm{E}(\mathrm{e})$ $=0$, dimana pembuktian matematika membutuhkan batasan

$$
\left[\begin{array}{cccc}
a_{11} & a_{12} & \Lambda & a_{1 n} \\
a_{21} & a_{22} & \Lambda & a_{2 n} \\
\Lambda & \Lambda & \Lambda & \Lambda \\
a_{m 1} & a_{m 2} & \Lambda & a_{m n}
\end{array}\right]\left[\begin{array}{l}
x_{1} \\
x_{2} \\
\Lambda \\
x_{n}
\end{array}\right]=\left[\begin{array}{l}
b_{1} \\
b_{2} \\
\Lambda \\
b_{m}
\end{array}\right]
$$

pada beta dan matrik covarian $\Omega=E\left[e e^{i}\right]$. Sebuah tambahan asumsi spesifik bahwa $E(e \mid f)=0$, tetapi asumsi ini tidak diperlukan dalam pengambangan model APT.

Jumlah dari aset, $\mathrm{n}$, diasumsikan berjumlah lebih banyak ketimbang jumlah faktor-faktor ekonomi (k). pada beberapa model, $\mathrm{n}$ adalah terhingga atau mendekati terhingga. Pada kasus ini, aset pertama dari $\mathrm{n}$ aset terhadap faktor $\mathrm{k}(\mathrm{n}+1)$ adalah sama dengan aset pada faktor $\mathrm{k}$ pada $\mathrm{n}$ baris pertama pada matrik beta pada faktor $\mathrm{k}(\mathrm{n}+1)$.

Seperti yang sudah dibahas diatas bahwa prediksi model APT pada pasar persaingan sempurna sehingga terdapat hubungan return saham dengan faktor-faktor ekonomi tertentu misalkan $\mathrm{k}$ faktor, maka APT dimulai dengan asumsi bahwa return pada berbagai saham $R_{i t}$ dihasilkan oleh sebuah model multi faktor (k-faktor) dari bentuk persamaan berikut (Roll dan Ross, 1980):

$$
R_{i t}=E\left(R_{i}\right)+b_{1 i} f_{1 t}+b_{2 i} f_{2 t}+\cdots+b_{i k} f_{k t}+\varepsilon_{i t}
$$

Dimana $E\left(R_{i}\right)$ adalah return harapan dari sekuritas/saham ke-i, $i=1,2,3, \ldots, \mathrm{n}, f_{k t}$ merupakan faktor ekonomi yang tidak dapat diamati, $k=1,2,3, \ldots, \mathrm{k}$, selanjutnya $b_{i k}$ merupakan sensitivitas sekurtias I terhadap faktor $\mathrm{k}$ dan adalah resiko idiosincratik pada saham i. sebagai tambahan bahwa ekspektasi dari faktor resiko yang muncul sama dengan nol dan $\varepsilon_{i t}=0$ untuk $i=1,2,3, \ldots, n$ serta ekspektasi resiko spesifik perusahaan terhadap sekuritas adalah nol, maka $\varepsilon_{i t}{ }^{2}=\sigma^{2}{ }_{e i}<\infty$.

Seperti keterangan diatas diasumsikan terdapat k-faktor $\left(I_{1}, I_{2}, \ldots, I_{k}\right)$ dan sekuritas ke j dipengaruhi oleh faktor-faktor yang diwakili dengan sensitivitas sekuritas terhadap faktor $\left(\beta_{i 1}, \beta_{2 j}, \ldots, \beta_{k j}\right)$, sehingga model APT dapat dibentuk dengan persamaan sebagai berikut (Nai Fu, 1986) :

$$
r_{j}=\alpha_{j}+\beta_{1 j} I_{1}+\beta_{2 j} I_{2}+\cdots+\beta_{j k} I_{k}+\varepsilon_{i}
$$


Dari persamaan diatas $\alpha_{j}$ adalah sebuah konstanta dari tingkat bebas resiko (return saham yang memiliki beta nol). Ross (1976) memperlihatkan jika jumlah saham cukup besar maka hubungan linier antara return dan resiko pada kondisi keseimbangan dapat ditulis :

$$
r_{j}=\gamma_{0}+\beta_{1 j} \gamma_{1}+\beta_{2 j} \gamma_{2}+\cdots+\beta_{j k} \gamma_{k}
$$

Untuk membentuk APT harus memahami konsep portofolio faktor (faktor portofolio) yang merupakan portofolio terdifersifikasi dengan baik dimana mempunyai beta 1 pada satu faktor dan nol pada faktor lain.yang merupakan tolak ukur untuk SML multifaktor. Selanjutnya multifaktor menyebutkan bahwa premi resiko bahwa premi resiko menyeluruh pada suatu porto dfolio sama dengan premi resiko yang dibutuhkan sebagai kompensasi atas setiap sumber resiko sistematis.

\section{Metodologi Penelitian}

\section{Pengujian Terhadap Model APT}

Fama dan French (1992) melakukan penelitian dan secara statistik signifikan menemukan hubungan antara beta dan return sekuritas dilihat dari beberapa faktor seperti ukuran perusahaan (Firm Size) dan rasio nilai buku berbanding nilai pasar perusahaam (Book to Market Ratio/BM Ratio), sehingga hasilnya mendukung argumen bahwa portofolio pasar merupakan resiko tunggal tidak mampu untuk menjelaskan return ratarata sehingga hanya bisa diterangkan dengan model multifaktor, salah satunya model APT. Sebenarnya APT sendiri merupakan perluasan model CAPM yang menggambarkan hubungan antara return harapan dan covarian return tersebut dengan variabel acak lainnya (pada model CAPM digambarkan dengan covarian return sekuritas deengan return portofolio pasar).

\section{Penentuan Faktor-faktor pada model APT}

Pada model CAPM return saham/sekuritas hanya bereaksi terhadap resiko pasar, maka pada model APT diyakini beereaksi terhadap peristiwa ekonomi. Beberapa perubahan yang terjadi pada variabel ekonomi makro akan mempengaruhi harga sekuritas dan beberapa variabel ekonomi makro lainnya bahkan tidak mempengaruhi sama sekali. Disamping itu terdapat perbedaan variabel ekonomi makro yang mempengaruhi pada masing-masing negara (Atlay, 2003). 
Pada dasarnya setiap kelebihan model pasti ada kelemahannya, model APT ternyata juga memiliki keterbatasan yaitu APT tidak menjelaskan faktor-faktor apa saja yang mempengaruhi return saham/sekuritas. Model APT sepertinya meninggalkan teka-teki yang harus diungkapkan oleh penelitipeneliti seelanjutnya dalam melakukan pengujian empiris dengan menggunakan model multifaktor. Salah satu penelitian dan pengujian terhadap model APT yang terkenal yang dilakukan oleh Chen, Roll dan Ross (1986) yang menganggap terdapat beberapa variabel ekonomi makro yang memiliki pengaruh signifikan dengan memiliki resiko sistematik pada return saham yaitu :

1. Inflasi - memiliki dampak terhadap tingkat diskonto dan arus kas masa depan bagi investor

2. Kondisi Struktur Tingkat Suku Bunga - perbedaan antara obligasi jangka pendek dan obligasi jangka panjang yang mempengaruhi nilai kewajiban masa depan dibandingkan dengan kewajiban jatuh tempo dalam waktu yang lebih singkat.

3. Risiko premium - perbedaan obligasi perusahaan bermutu rendah dan obligasi perusahaan bermutu tinggi mendekati reaksi pasar terhadap risiko.

4. Produksi-industri - perbedaan dalam produksi industri berdampak pada peluang investasi dan nilai riil arus kas.

Beberapa studi empiris lainnya dari model APT berfokus pada penentuan jumlah faktor yang secara sistematis menentukan return saham dengan menerapkan model analisa faktor. Sejumlah besar makalah dan jurnal keuangan menggunakan metode analisa faktor seperti yang dilakukan oleh Chen Roll dan Ross (1980) yang menemukan 3 sampai 4 faktor resiko sistematis yang secara statistik cukup untuk menjelaskan return saham pada periode 1962-1974, disisi lain Chen (1983) menemukan terdapat 5 faktor pada NYSE dan AMEX antara 1963-1978, Dhrymes et at (1985) menemukan sejumlah perubahan faktor tergantung pada panjang periode yang digunakan dan ukuran dari kelompok saham dalam analisa dengan menggunakan informasi tambahan dalam kaitan hubungan return dengan peristiwa-peristiwa makro ekonomi.

Memperkirakan faktor risiko tak terduga, selanjutnya beberapa portofolio dibangun untuk menguji prosedur. Pada tahap pertama, koefisien beta faktor portofolio masing-masing diperkirakan dengan regresi time series, dan pada tahap kedua proses regresi cross sectional dijalankan untuk memperkirakan hubungan antara beta faktor dan return rata-rata aset/sekuritas.

Pada penelitin ini, penulis menggunakan metodologi pengujian dua tahap yang banyak digunakan di kedua pengujian empiris model CAPM dan APT, seperti yang dilakukan oleh Fama Macbeth (1973), Roll dan Ross (1980), Chen (1983), Chen, Roll dan Ross (1986). 


\title{
Desain Penelitian
}

\author{
Metodologi \\ Dalam mode APT, tidak menyebutkan faktor risiko apa saya yang dimasukkan dalam penelitian, dalam hal \\ ini memberikan kebebasan peneliti menggunakan faktor ekonomi makro dengan selalu memasukkan risiko \\ pasar (Gul and Khan, 2013). Penulis menggunakan 13 variabel ekonomi makro yang kemudian disaring \\ menggunakan Principal Component Analysis (PCA). Dengan menggunakan PCA, kemudian diperoleh 3 \\ variabel yaitu kurs USD, inflasi dan risiko pasar dengan menggunakan proksi LQ45.
}

\section{Populasi dan Sampel Penelitian}

Penelitian kali ini mengambil rentang waktu selama 5 tahun dengan rentang menjadi 60 bulanan mulai dari tahun 2014 sampai dengan tahun 2018. Populasi penelitian disini adalah seluruh saham-saham yang tergabung dalam indeks LQ 45 yang menggunakan saham-saham berdasarkan syariah Islam, sehingga dalam rentang waktu penelitian akan ada beberapa saham yang akan tereliminasi dikarenakan tidak memenuhi kriteria penelitian. Tehnik pengambilan sampel menggunakan purposive random sampling dengan merangking saham-saham LQ45 berdasarkan kapitalisasi pasar. Setelah didapat beberapa saham memenuhi kriteria, peneliti membentuk portofolio saham dimana 1 portofolio terdiri dari 5 saham yang dibentuk berdasarkan kapitalisasi pasar. Portofolio satu terdiri dari lima saham dengan kapitalisasi pasar yang tertinggi begitu selanjutnya dan didapat 5 portofolio dengan jumlah keseluruhan terdiri dari 20 saham.

Langkah selanjutnya adalah melakukan pemilihan variabel ekonomi makro yang dengan berpedoman pada kerangka konsep model APT bahwa tingkat imbal hasil sekuritas dipengaruhi oleh faktor ekonomim akan tetapi Ross (1976) tidak merincikan faktor ekonomi mana saja yang dimasukkan dalam penelitian. Hal ini mempermudah peneliti untuk memasukkan sembarang variabel ekonomi makro dan besarnya jumlah variabel ekonomi yang akan dimasukkan. Pada penelitian ini, variabel yang akan dimasukkan adalah tingkat inflasi, Kurs US Dollar terhadap mata uang Rupiah, dan Indeks Pasar Modal LQ45 setelah melalui uji saring menggunakan PCA.

\section{Operasional Variabel}

Peneliti menggunakan 4 variabel dalam menguji keandalan model APT dalam memprediksi imbal hasil portofolio saham dengan faktor risiko sebagai variabel bebas. Adapun definisi variabelnya dirincikan dalam tabel dibawah ini :

\section{Tabel 1}


Operasional Variabel

\begin{tabular}{|c|c|c|}
\hline Variabel/ Konsep & Formula & Skala \\
\hline $\begin{array}{c}\text { Imbal Hasil Portofolio }\left(R_{p}\right), \text { Ross } \\
\text { (1976); Gul and Khan, } 2013\end{array}$ & $\begin{array}{r}R p=w_{1} R_{s}+w_{2} R_{2}+\cdots \\
+w_{n} R_{n}\end{array}$ & Rasio \\
\hline $\begin{array}{l}\text { Kurs USD terhadap Rupiah, Atlay } \\
\text { (Atlay, 2004) }\end{array}$ & 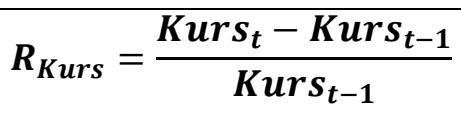 & Rasio \\
\hline Inflasi, Tripathi (2014) & $\begin{array}{l}R_{\text {Inflasi }} \\
=\frac{\text { Inflasi }_{t}-\text { Inflasi }_{t-1}}{\text { Inflasi }_{t-1}}\end{array}$ & Rasio \\
\hline Risiko Pasar (Beta), Drew (2010) & $R_{L Q 45}=\frac{L Q 45_{t}-L Q 45_{t-1}}{L Q 45_{t-1}}$ & Rasio \\
\hline
\end{tabular}

Sumber : Olahan Sendiri

\section{Metode Analisis}

Metode analisi data menggunakan Two Stage Regression dalam menguji model APT, dimana regresi jalur pertama menggunakan regresi runtut waktu (Time-Series Regression) dengan tujuan memperoleh beta estimasi masing-masig faktor pada pasing-masing portofolio.

\section{Regresi runtut waktu (Time-Series Regression)}

Setelah beta portofolio dibentuk berdasarkan ukuran perusahaan yang telah dilakukan pada pada langkah diatas yang menghasilkan 5 portofolio, dimana return rata-rata bulanan tiap-tiap portofolio dihitung. Persamaan regresi time series yang dipakai, mengerucut pada pengujian yang dilakukan oleh Chen (1983) dengan menggunakan 3 variabel ekonomi makro dan risiko pasar dengan persamaan sebagai berikut :

$$
R_{P, t}=\alpha_{0}+\gamma_{1} F_{1, t}+\gamma_{2} F_{2, t}+\gamma_{3} F_{3, t}+\varepsilon_{t}
$$

Setelah dilakukan regresi Time Series, kemudian data dilakukan treatment, dengan melakukan uji asumsi klasik menggunakan uji Normalitas, Kolinieritas, Auto Korelasi dan Heteroskedastilitas, hal ini sesuai dengan kaidah statistik bahwa jika sebuah model keuangan akan diuji, maka perlu dilakukan pengujian data menggunakan asumsi klasik disebabkan data harus bersifat BLUE (Best Linier Unbias Estimation) (Said dan Chandra, 2005).

\section{Regresi sesi silang (Cross Sectional Regression)}

Untuk menguji non-linieritas antara return portofolio dengan faktor-faktor ekonomi, maka penulis menggunakan persamaan yang diuraikan dengan rumus dibawah ini : 


$$
\overline{R_{p}}=\varphi_{0}+\varphi_{1} \gamma_{1}+\varphi_{1}{ }^{2} \gamma_{1}+\varphi_{2} \gamma_{2}+\varphi_{2}^{2} \gamma_{2}+\varphi_{3} \gamma_{3}+\varphi_{3}{ }^{2} \gamma_{3}+\varepsilon_{p}
$$

Disebutkan jika model APT valid, maka $\varphi_{0}, \varphi_{1}{ }^{2}, \varphi_{2}{ }^{2}, \varphi_{3}{ }^{2}, \varphi_{4}{ }^{2}$ seharusnya sama dengan nol, hal ini menentukan ke absahan model tersebut dalam pasar modal yang diuji.

Tabel 1 : Estimasi Rregresi Time Series dari Koefisien Faktor Beta Pada Saham-saham yang tergabung Dalam Indeks LQ45 Melalui Portofolio Saham

$$
R_{P, t}=\alpha_{0}+\gamma_{1} F_{1, t}+\gamma_{2} F_{2, t}+\gamma_{3} F_{3, t}+\gamma_{4} F_{4, t}+\varepsilon_{t}
$$

\begin{tabular}{|c|c|c|c|c|c|c|c|c|c|c|c|}
\hline & & & \multicolumn{3}{|c|}{ Inflasi } & \multicolumn{3}{|c|}{ Kurs USD } & \multicolumn{3}{|c|}{ Risiko Pasar } \\
\hline & $R$ & R Sqr & $\hat{Y} 1$ & T-Stat & Sig & $\hat{Y} 2$ & T-Stat & Sig & $\hat{Y} 4$ & T-Stat & Sig \\
\hline \begin{tabular}{|l|} 
Portofolio 1 \\
\end{tabular} & 0,861 & 0,739 & $-0,007$ & $-0,086$ & 0,932 & $-0,105$ & $-1,284$ & 0,206 & 0,880 & 10,485 & 0,000 \\
\hline Portofolio 2 & 0,721 & 0,52 & $-0,053$ & $-0,482$ & 0,632 & $-0,002$ & $-0,018$ & 0,986 & 0,708 & 6,213 & 0,000 \\
\hline Portofolio 3 & 0,733 & 0,537 & 0,128 & 1,191 & 0,241 & $-0,025$ & $-0,234$ & 0,816 & 0,758 & 6,779 & 0,000 \\
\hline Portofolio 4 & 0,628 & 0,394 & $-0,133$ & $-1,079$ & 0,287 & 0,131 & 1,052 & 0,299 & 0,538 & 4,204 & 0,000 \\
\hline Portofolio 5 & 0,442 & 0,196 & 0,345 & 2,429 & 0,020 & $-0,001$ & \begin{tabular}{|l|}
$-0,005$ \\
\end{tabular} & 0,996 & 0,365 & 2,477 & 0,017 \\
\hline
\end{tabular}

Hasil regresi tahap satu atau regresi Time Series dirangkum dalam tabel berikut ini :

Hasil regresi tahap satu atau regresi Time Series diperoleh bahwa dari tiga variabel ekonomi makro (Inflasi, Kurs USD dan Risiko Pasar) yang dimasukkan dalam penelitian, hanya risiko pasar yang memiliki pengaruh yang paling kuat secara statistik signifikan. Ini memperkuat bukti bahwa model APT tidak sanggup dalam menerangkan Return portofolio saham Syariah yang tergabung dalam LQ 45. Temuan ini sejalan dengan model yang diperkenalkan oleh William Sharpe (1964), Lintner (1965) dan Mosin (1966) yang menggambarkan trade-off antara return sekuritas dengan risiko tunggal yaitu risiko pasar. Hasil penelitian empiris ini juga sejalan dengan penelitian empiris terdahulu yang dilakukan oleh Lintner, dikutip oleh Douglas (1968), Black, Jensen dan Scholes (1972), Blume dan Friend (1973) serta Fama dan Macbeth (1973). Untuk hasil sementara bahwa model APT masih belum bisa menggunguli model CAPM dikarenakan risiko pasar memiliki pengaruh yang kuat terhadap Return portofolio ketimbang risiko ekonomi makro lainnya yang dimasukkan dalam penelitian ini. Selain itu beberapa portofolio ada yang terpapar eksposur inflasi secara statistik insignifikan terkait imbal hasil portofolio 1, 3 dan 4. Dilain hal, 
eksposur risiko perubahan Kurs US Dollar terhadap imbal hasil portofolio saham model APT juga memiliki pengaruh inversi walaupun tidak signifikan secara statistik.

Selanjutnya, dari hasil regresi Time Series juga diperoleh bahwa terdapat hubungan linieritas antara risiko pasar dengan return portofolio, hal ini diperlihatkan dengan besaran pengaruh antara risiko pasar dengan portofolio yang dibentuk, semakin besar saham-saham perusahaan yang tergabung dalam suatu portofolio akan semakin dipengaruhi oleh risiko pasar, sedangkan risiko ekonomi makro lainnya kurang memiliki pengaruh yang cukup kuat. Kemudian, portofolio yang dibentuk dari gabungan saham-saham perusahaan yang memiliki kapitalisasi pasar yang kecil memperlihatkan pengaruh variabilitas yang sangat lemah. Nilai yang besar dari T-statistik menyatakan bahwa pengaruh premi pasar sangat kuat terhadap return portofolio kertimbang faktor ekonomi makro lainnya, pada tingkat signifikansi 0,05, karena T-Statistik disini menggambarkan qualitas suatu model dimana dari tabel diatas bernilai tinggi intuk keseluruhan portofolio. Bukti permulaan ini sudah menunjukkan bahwa model CAPM menggunguli model APT dalam menerangkan antara hubungan risiko dan return sekuritas dan risiko mana saja yang mesti dipertimbangkan oleh investor.

Tahapan pengujian selanjutnya sama dengan pengujian model CAPM yaitu regresi cross sectional berdasarkan data yang diperoleh pada regresi time series. Data yang akan dipergunakan pada regresi cross sectional diperlihatkan pada tabel berikut :

Tabel 1 : Hasil Rregresi Cross Sectional dari Koefisien Faktor Beta Pada Saham-saham yang tergabung Dalam Indeks LQ45 Melalui Portofolio Saham

\begin{tabular}{|c|c|c|c|c|c|c|}
\hline \multirow{2}{*}{\multicolumn{2}{|c|}{ Model }} & \multicolumn{2}{|c|}{ Unstandardized Coefficients } & \multirow{2}{*}{$\begin{array}{l}\text { Standardized } \\
\text { Coefficients } \\
\text { Beta }\end{array}$} & \multirow[b]{2}{*}{$\mathrm{t}$} & \multirow[b]{2}{*}{ Sig. } \\
\hline & & B & Std. Error & & & \\
\hline \multirow[t]{4}{*}{1} & (Constant) & ,021 &, 020 & & 1,034 &, 489 \\
\hline & Binflasi &,- 039 &, 026 & $-1,221$ & $-1,486$ &, 377 \\
\hline & Bkurs &,- 107 &, 063 & $-1,544$ & $-1,719$ &, 335 \\
\hline & Bpasar &,- 023 &, 029 &,- 785 &,- 801 &, 570 \\
\hline
\end{tabular}

Untuk pengujian parameter estimasi, maka t-statistik digunakan dengan membangun hipotesa sebagai berikut :

$H_{0}: \varphi_{0}=0$, maka parameter Inflasi adalah staistik insignifikan 


$$
H_{0}: \varphi_{0} \neq 0 \text {, maka parameter Inflasi adalah statistik signifikan }
$$

Pada tingkat signifikan $\alpha=0,05$ dimana $P$-Value dari t-statistik sama dengan 0 , yang mengarahkan pada kesimpulan bahwa tidak terdapat cukup bukti untuk menolak $H_{0}$, oleh karena itu parameter $\Upsilon 0$ selaku konstanta atau intersept adalah statistik insignifikan.

$H_{0}: \varphi_{1}=0=I N F L A S I_{-} C S$, maka parameter Inflasi tidak mempengaruhi return rata-rata portofolio $\left(\overline{R_{p}}\right)$

$$
H_{0}: \varphi_{1}=0 \neq I N F L A S I \_C S \text {, maka parameter Inflasi mempengaruhi return rata-rata }\left(\overline{R_{p}}\right)
$$

Pada tingkat signifikansi $\alpha=0,05 P$-Value dari nilai t-statistik sama dengan 0,377 yang mengarahkan kepada kesimpulan bahwa tidak terdapat cukup bukti untuk menolak $H_{0}$, oleh karena itu variabel $\Upsilon_{1}$ (Inflasi) tidaklah berpengaruh terhadap rata-rata return portofolio.

$H_{0}: \varphi_{2}=K U R S \_C S=0$, maka parameter kurs US Dollar Amerika Serikat tidak mempengaruhi return rata-rata portofolio $\left(\overline{R_{p}}\right)$

$$
H_{0}: \varphi_{2}=K U R S_{-} C S \neq 0 \text {, maka parameter kurs US Dollar Amerika k mempengaruhi return rata- }
$$
$\operatorname{rata}\left(\overline{R_{p}}\right)$

Pada tingkat signifikansi $\alpha=0,05 P$-Value dari nilai t-statistik sama dengan 0,335 yang mengarahkan kepada kesimpulan bahwa tidak terdapat cukup bukti untuk menolak $H_{0}$, oleh karena itu variabel $\Upsilon_{2}$ (Kurs US Dollar) tidaklah berpengaruh terhadap rata-rata return portofolio.

$$
H_{0}: \varphi_{4}=\text { Resiko Pasar }=0 \text {, maka parameter Risiko Pasar tidak mempengaruhi return rata-rata }
$$
portofolio $\left(\overline{R_{p}}\right)$

$$
H_{0}: \varphi_{4}=\text { Resiko Pasar } \neq 0 \text {, maka parameter Risiko Pasar mempengaruhi return rata-rata }\left(\overline{R_{p}}\right)
$$

Pada tingkat signifikansi $\alpha=0,05 P$-Value dari nilai t-statistik sama dengan 0,570 yang mengarahkan kepada kesimpulan bahwa tidak terdapat cukup bukti untuk menolak $H_{0}$, oleh karena itu variabel $\Upsilon_{2}$ (Risiko Pasar) tidaklah berpengaruh terhadap rata-rata return portofolio.

Kemudian, peneliti melakukan pengujian linieritas variabel residual atau Error Term terhadap Return portofolio model APT, dengan melakukan regresi variabel residual terhadap imbal hasil portofolio model APT yang telah dibentuk. Dalam kajian teoritis dibahas bahwa seharusnya variabel residual tidak perlu dihargai, dengan kata lain bahwa variabel ini tidak memiliki pengaruh terhadap return portofolio dengan hipotesa sebagai berikut : 
$H_{0}: \boldsymbol{\eta}_{\boldsymbol{p}}>\mathbf{0 , 0 5}$, maka komponen residual tidak memiliki pengaruh terhadap imbal hasil P_APT

$H_{0}: \boldsymbol{\eta}_{\boldsymbol{p}}<\mathbf{0}, \mathbf{0 5}$, komponen residual mempengaruhi imbal hasil P_APT

Tabel 3 : Hasil Regresi Variabel Residual Model APT

\section{Coefficients $^{\mathrm{a}}$}

\begin{tabular}{|c|c|c|c|c|c|c|}
\hline \multirow{2}{*}{\multicolumn{2}{|c|}{ Model }} & \multicolumn{2}{|c|}{ Unstandardized Coefficients } & \multirow{2}{*}{$\begin{array}{c}\text { Standardized } \\
\text { Coefficients } \\
\text { Beta }\end{array}$} & \multirow[b]{2}{*}{$\mathrm{T}$} & \multirow[b]{2}{*}{ Sig. } \\
\hline & & B & Std. Error & & & \\
\hline \multirow[t]{2}{*}{1} & (Constant) & ,004 & ,003 & & 1,270 & ,294 \\
\hline & Unstandardized Residual & 1,000 & 1,645 & ,331 & ,608 &, 586 \\
\hline
\end{tabular}

Dari keterangan tabel diatas, diketahui nilai signifikansi lebih besar dari 0,05 dengan taraf keyakinan 95\% yaitu sebesar 0 , bahwa tidak terdapat cukup bukti untuk menolak $H_{0}$, oleh karena itu elemen residual $\boldsymbol{\eta}_{\boldsymbol{p}}$ tidak memiliki pengaruh terhadap R_APT.

Dalam melakukan pengujian model APT, dikatakan bahwa variabel residual harus terdistribusi normal. Peneliti melakukan pengujian variabel residual menggunakan pengujian sampel searah kolmogorof smirnov dengan membentuk hipotesa

Tabel 4 : Pengujian Normalitas Variabel Residual

One-Sample Kolmogorov-Smirnov Test

Unstandardize

d Residual

\begin{tabular}{llr}
\hline N & & 5 \\
\hline Normal Parameters & & Mean \\
\cline { 2 - 3 } & Std. Deviation &, 00195656 \\
\hline Most Extreme & Absolute &, 239 \\
\cline { 2 - 3 } Differences & Positive &, 239 \\
\cline { 2 - 3 } & Negative &,- 172 \\
\hline Test Statistic & &, 239 \\
\hline Asymp. Sig. (2-tailed) & &, $200^{\text {c,d }}$ \\
\hline
\end{tabular}

a. Test distribution is Normal.

$$
H_{0}: \boldsymbol{\eta}_{\boldsymbol{p}}>\mathbf{0 , 0 5} \text {, maka komponen residual berdistribusi normal }
$$




\section{$H_{0}: \boldsymbol{\eta}_{\boldsymbol{p}}<\mathbf{0 , 0 5}$, maka komponen residual tidak berdistribusi normal}

Dari keterangan tabel diatas, diketahui nilai Kolmogrof-Smirnov sebesar 0,200 yang lebih besar dari $\alpha=0,05$, sehingga dapat ditarik kesimpulan bahwa tidak terdapat cukup bukti untuk menolak $H_{0}$, oleh karena itu elemen residual $\boldsymbol{\eta}_{\boldsymbol{p}}$ berdistribusi normal.

\subsubsection{Pengujian non-linieritas model APT}

Untuk menguji non-linieritas antara return portofolio dengan faktor-faktor ekonomi, maka digunakan persamaan yang diuraikan dengan rumus dibawah ini :

$$
\overline{R_{p}}=\varphi_{0}+\varphi_{1} \gamma_{1}+\varphi_{1}^{2} \gamma_{1}+\varphi_{2} \gamma_{2}+\varphi_{2}^{2} \gamma_{2}+\varphi_{3} \gamma_{3}+\varphi_{3}^{2} \gamma_{3}+\varepsilon_{p}
$$

Disebutkan jika model APT valid, maka $\varphi_{0}, \varphi_{1}{ }^{2}, \varphi_{2}{ }^{2}, \varphi_{3}{ }^{2}$ seharusnya sama dengan nol, hal ini menentukan ke absahan model tersebut dalam pasar modal yang diuji. Hasil yang diperoleh diperlihatkan pada tabel dibawah ini :

Tabel 5 : Pengujian non-sistematis terhadap model APT

\begin{tabular}{|c|c|c|c|c|c|c|}
\hline \multirow{2}{*}{\multicolumn{2}{|c|}{ Model }} & \multicolumn{2}{|c|}{ Unstandardized Coefficients } & \multirow{2}{*}{$\begin{array}{l}\text { Standardized } \\
\text { Coefficients } \\
\text { Beta }\end{array}$} & \multirow[b]{2}{*}{$\mathrm{t}$} & \multirow[b]{2}{*}{ Sig. } \\
\hline & & $\mathrm{B}$ & Std. Error & & & \\
\hline \multirow[t]{4}{*}{1} & (Constant) &,- 002 & ,016 & &,- 132 & ,916 \\
\hline & BInf2 &,- 016 &, 131 &,- 132 &,- 119 & ,924 \\
\hline & BKurs2 &,- 193 &, 512 &,- 259 &,- 377 &, 770 \\
\hline & BPasar2 & ,016 & ,024 & 689 & ,669 & 625 \\
\hline
\end{tabular}

Pada tabel diatas diperoleh hasil $\varphi_{1}{ }^{2}, \varphi_{2}{ }^{2}, \varphi_{3}{ }^{2}$ secara statistik insignifikan mempengaruhi rata-rata return portofolio, hal ini dilihat dari nilai signifikansi masing-masing sebesar 0,924, 0,770, dan 0,625 yang lebih besar dari taraf signifikansi sebesar $\alpha=0,05$. Hal berlawanan dengan model bahwa seharusnya $\varphi_{1}{ }^{2}, \varphi_{2}{ }^{2}, \varphi_{3}{ }^{2}$ sama dengan nol.

Berdasarkan hasil pengujian keseluruhan diatas, versi model APT yang disajikan dalam penelitian ini tidak bekerja dengan baik pada pasar modal di Indonesia, terutama saham-saham unggulan dengan proksi pasar indeks LQ45. Semua pengujian kelihatannya tidak secara statistik signifikan mempengaruhi retrurn 
portofolio. Kesimpulan keseluruhan setelah menguji model APT pada pasar modal Indonesia sepertinya kurang bekerja, tetapi model CAPM masih mengungguli model APT dari keseluruhan pengujian.

\section{Kesimpulan}

Pengujian empiris terhadap model keseimbangan pasar modal model APT tidak bekerja dengan baik pada pasar modal Indonesia, terutama saham-saham yang tergabung dalam indeks 45, hal ini terlihat dari signifikansi masing-masing variabel ekonomi makro yang dimasukkan dalam penelitian tidak mampu menerangkan hubungan risiko dengan imbal hasil rata-rata portofolio saham, sehingga mengindikasikan bukti menentang model APT. Kemudian, model APT menunjukkan bahwa tidak satupun faktor-faktor ekonomi yang dipilih dan dimasukkan dalam penelitian menunjukkan hubungan linier dengan imbal hasil rata-rata portofolio, oleh karena itu temuan dalam penelitian tidak konsisten dengan hipotesis model APT dan menunjukkan bukti kuat menentang model APT. Pembahasan lanjutan menunjukkan adanya kesamaan penelitian ini dengan model APT bahwa risiko spesifik perusahaan tidak perlu dihargai dan dapat dihilangkan dengan melakukan diversifikasi, sehingga faktor sistematik saja yang perlu dipertimbangkan terhadap imbal hasil portofolio saham.

\section{Implikasi}

Memberikan panduan kepada investor terkait hubungan antara imbal hasil sekuritas dengan faktor risiko yang menyertainya. Dalam hal ini pengujan ini membuktikan bahwa investor dapat mempertimbangkan model lain yang lebih valid dalam menjelaskan hubungan antara imbal hasil sekuritas dengan faktor-faktor apa yang akan digunakan dalam mencari Abnormal Return.

Hasil penelitian ini digunakan sebagai masukan bagi analis pasar modal dan investor, dalam melakukan analisis investasi yang memberikan petunjuk bahwa model keseimbangan pasar pada saham-saham yang tergabung dalam LQ45 resisten terhadap variabel ekonomi makro yaitu inflasi dan perubahan kurs valuta asing terhadap mata uang lokal, akan tetapi mampu bekerja dengan baik menggunakan risiko beta pasar yang diproksikan dengan indeks LQ45. 


\section{Keterbatasan Penelitian}

Penelitian ini hanya menggunakan sedikit faktor risiko yaitu hanya 13 variabel ekonomi makro dengan menggunakan tehnik PCA, sehingga hanya lulus 3 variabel ekonomi makro. selanjutnya dalam penelitian ini periode pengamatan sangat singkat yaitu 60 bulan atau periode 5 tahunan, sedangkan Wang et al (2011) menganjurkan periode minimal adalah sebanyak 100 observasi, hal ini untuk menghindari terjadinya gangguan statistik pada regresi tahap dua. Oleh sebab itu, ia mengusulkan jika menggunakan data 10 tahunan dengan periode 10 tahun, sehingga diperoleh 120 bulan atau 120 observasi.

\section{Daftar Pustaka}

Andres Bello, Jan Smolarski, Gokce Soydemir and Linda Acevedo, (2017), "Investor Behavior: Hedge Fund Returns and Strategiesi”, Vol. 9 Issue: 1,pp. 14-42, doi: 10.1108/ RBF-09-2015-0036 Permanent link to this document: http://dx.doi.org/10.1108/RBF-09-2015-0036

Al-Khazali, O.M, dan C.S. Pyun. 2004."Stock Price and Inflation: New Evidence from Pasific-Basin Countries", Review of Quantitative Finance and Accounting. Vol. 22 (2) Hal, 123-140Authors, F. (2017). Review of Behavioral Finance Article information : https://doi.org/10.1108/RBF-09-20150036

Baghdadabad, M. R. T., \& Glabadanidis, P. (2014). An extensile method on the arbitrage pricing theory based on downside risk (D-APT). International Journal of Managerial Finance, 10(1), 54-72. https://doi.org/10.1108/IJMF-12-2011-0095

Rjoub, H., Türsoy, T., \& Günsel, N. (2009). The effects of macroeconomic factors on stock returns: Istanbul stock market. Studies in Economics and Finance, 26(1), 36-45. https://doi.org/10.1108/10867370910946315

Black. F, Jensen, M.C, dan Scholes. M, (1972), “The Capital Asset Pricing Model : Some Empirical Test”"

Black, Fischer, Michael C. Jensen and Myron Scholes. (1972). "The Capital Asset Pricing Model: Some Empirical Tests," in Studies in the Theory of Capital Markets. Michael C. Jensen, ed. New York: Praeger, pp. 79-121.

Blume, Marshall and Irwin Friend. 1973. "A New Look at the Capital Asset Pricing Model." Journal of Finance. 28:1, pp. 19-33.1

Bodie, Kane dan Marcus, 2005, “Investment”, Edisi ke Enam, Mc Grew Hill

Canegrati, Emanuele (2008), "Testing the CAPM: Evidences from Italian Equity Markets" Universita Cattolica Milano

Charles P. Jones (2010), "Investment Principal and Concept", Eleventh Edition, North Carolina State University 
Chen, N.F., R.Roll and S.Ross (1986), "Economic Forces and the Stock Market", Journal of Business, Vol.59, pp.383-403

Douglas, George W. (1968). Risk in the Equity Markets: An Empirical Appraisal of Market Efficiency. Ann Arbor, Michigan: University Microfilms, Inc.

Erdinc Altay, 2003. "The Effect of Macroeconomic Factors on Asset Returns: A Comparative Analysis of the German and the Turkish Stock Markets in an APT Framework". Journal of Finance, Istambul University, Faculty of economic.

Eugene F. Fama dan Kenneth R. French, (2004), Draft Kedua, “The Capital Asset Pricing Model”, artikel Keuangan

Fama, E. F., dan MacBeth, J., 1974, "Test of multiperiod two parameter model", journal of finance, 47 (juni)

Fama, E.F. and K.R.French (1992), “The Cross-section of Expected Stock Returns”,Journal of Finance, Vol.47, no.2, pp.427-466.

Geske R. and R. Roll. "The Fiscal and Monetary Linkage between Stock Returns and Inflation" Journal of Finance, 1983, Vol. 38, No. 1, pp. 7-33.

Gibbons, M.R. (1982), “Multivariate Tests of Financial Models", Journal of Financial Economics, Vol.10, pp.3-27.

Harry Markowitz, 1952, "Portofolio Selection”, The Journal of Finance, Vol. 7, No. 1. (Mar., 1952), pp. $77-91$.

Lakonishok, J. and A.C.Shapiro (1986), "Systematic Risk, Total Risk and Size as Determinants of Stock Market Returns", Journal of Banking and Finance, Vol.10, pp.115-132.

Mark J. Flannery , Aris Protopapadakis, 2002, “Macroeconomic Factors Do Influence Aggregate Stock Returns"

Michael Drew, (2010), “Beta, Firm Size, Book-to-Market Equity and Stock Returns”, Journal of the Asia Pacific Economy, 354-379, Journal of the Asia Pacific Economy, http://dx.doi.org/10.1080/13547860306289\}

Nai Fu Chen, 1983, "Some Empirical Tests of the Theory of Arbitrage Pricing", Journal of Finance, The Journal of The American Finance Association

Phoebus J. Dhrymes, Irwin Friend, Mustafa N. Gultekin, N. Bulent Gultekin, 1985, "New Tests of the APT and Their Implications", Journal of Finance, The Journal of The American Finance Association

Richard Roll dan Sthephen Ross, 1980,"An Empirical Investigation of Arbiterage Pricing Theory", Journal of Finance, 36(3):313-321

Said Kelana dan Chandra Wijaya 2005, Riset Keuangan, "Pengujian-Pengujian Empiris", Gramedia Pustaka Utama 
Stephan A. Ross"Return, Risk and Arbiterage" I. Friend dan J. Bicker, ed, (1976), Risk and Return in Finance, Cambridge MA: Ballinger

Stephan A. Ross, 1976, “Arbiterage Theory of Capital Assets Pricing”, Journal of Economic Theory, 13, 341-360 (1976), Departement of Economic and Finance, University of Pennsylvania, The Wharton School, Philadelphia

Reinganum, M. (1981), “The Arbitrage Pricing Theory: Some Empirical Results”, The Journal of Finance, Vol.37, pp.1037-1042.

Authors, F. (2017). Review of Behavioral Finance Article information : https://doi.org/10.1108/RBF-092015-0036

Baghdadabad, M. R. T., \& Glabadanidis, P. (2014). An extensile method on the arbitrage pricing theory based on downside risk (D-APT). International Journal of Managerial Finance, 10(1), 54-72. https://doi.org/10.1108/IJMF-12-2011-0095

Rjoub, H., Türsoy, T., \& Günsel, N. (2009). The effects of macroeconomic factors on stock returns: Istanbul stock market. Studies in Economics and Finance, 26(1), 36-45. https://doi.org/10.1108/10867370910946315

William Sharpe (1964), "Capital Asset Prices : A theory of market equilibrium under conditions of risk" Journal of finance.

Vanita Tripathi (2014), "Relationship between Inflation and Stock Returns - Evidence from BRICS markets using Panel Co integration Test" International Journal of Accounting and Financial Reporting, ISSN 2162-3082, 2014, Vol. 4, No. 2, Doi:10.5296/ ijafr.v4i2.6671 URL: http://dx.doi.org/10.5296/ ijafr.v4i2.6671 